\title{
MISCELLANY
}

\section{SPANISH INFLUENCE ON ENGLISH WORD-FORMATION: THE SUFFIX -ISTA}

Spanish influence on the English language was particularly important in the sixteenth century, at a time when Spain was a world military and political power in conflict with the British, and it gained a new momentum when Spain set foot in America. The best reflection of this influence is the great number of Spanish loanwords in present-day English, especially in its American variety.

Because of the intimate contact of Spanish with English in the US, Spanish has also left an imprint on English derivational morphology, and this is something that cannot be said of most other living languages-such as Japanese-which also exert a significant influence on present-day English (cf. Cannon 1981; forthcoming). The suffixes or combining forms that betray Spanish origin include the prolific -teria of cafeteria and the "parasitic"-aroo (jivaroo, wackaroo, etc.) and -eroo (swingeroo, siinkeroo, etc.) which appeared in American English in the 1930s by analogy with buckaroo (< Sp. vaquero 'cowboy') and the coincidental support of kangaroo (cf. Bolinger 1941, 306; Wentworth 1942). I call -aroo "parasitic" in that it lacks the "transcategorizing" function which is proper of suffixes, for it is used simply to create amusing, slangy variations of whatever is prefixed.

This slangy character is also present in other American combining forms of recent creation such as -esta $(<$ fiesta) which denotes extra fanfare, celebration, and the like (e.g., jubilesta $[<j u b i l e e]$, Hallowesta $<$ Halloween]) and $e l-o$ (< common pattern among Spanish singular masculine nouns) which constitutes an amusing variation of whatever is infixed (el cheapo 'cheap product', el ropo, ${ }^{1}$ etc.) (cf. Murray, forthcoming).

Still more recent is the incorporation of the Spanish suffix -ista to English wordstock. Given its novelty, the discussion of its origin and specific uses and meanings, in contrast with English -ist, will be the main object of this article.

\section{-IST/-ISTA VARIATION}

The agentive suffix -ist has a long tradition in English. Deriving ultimately from Greek -istes, it was introduced during Middle English by way of French versions of latinized Greek ecclesiastical terms, such as baptist, exorcist, and evangelist (Dressman 1985). Over time, the suffix has developed a variety of uses and meanings which are not different from their paronymous counterparts in the Romance languages (French-iste, Sp. Port. It. -ista) as 
well as German -ist. Ever since the French Revolution, one particularly fertile area for the growth of this suffix has been politics, where numerous names make use of it to refer to the adherents to a political system or thought (capitalist, socialist, communist). The high frequency of use of such words owes a great deal to the spread of the pattern (cf. Rodríguez 1988). Furthermore, in the political field the suffix has been reinforced by the presence of-ism (capitalism, socialism, communism) with which it forms a pair.

Despite the solid establishment of -ist/-ism in present-day English, Spanish borrowings with -ista/-ismo are common with derivatives of ideological characterization, sometimes giving rise to morphemic variation (sinarquist) sinarchista, caciquism/caciquismo). A good number of them are eponyms, that is, derived from proper names; for example, Carlista/Carlist (< Carlos [Hugo de Borbón]); franquista/Francoist (< Franco), Peronista/Peronist (< Perón), Somocista/Somozist (< Somoza), Sandinista/Sandinist (< Sandino), and fidelismo/fidelism (<Fidel [Castro] which aiso alternate with Castroism).

One can argue that the forms in -ist (and-ism), on the whole, constitute a higher degree of lexicalization, so that Peronism, Francoist, Carlist, like Castroism, are the most usual forms and as such they have been registered in dictionaries. But one cannot say the same of sinarchist, somozist, and Sandinist, which I have been able to document only very occasionally. In marked contrast, the Hispanic variant Sandinista, during the ten-year duration of the left-wing Nicaraguan government and its woridwide political attention, acquired a notably high frequency of use, well above many other similar borrowings in the English-speaking media, therefore serving as an analogical base or reinforcement for other formations, as witness somocista, placed within the same political context, as well as others such as Stronista ([Alfredo] Stroessner, Paraguay) and Alanista (Alán [García], Peru). This pattern contrasts with earlier times when Carlist, Francoist, and Peronist were found to be the variants established by usage and thereby registered in general as well as specialized dictionaries. In one case, Guevarist (< [Che] Guevara), attested in 1968 for the first time, the English -ist was the only suffix found (cf. Cannon 1994, 121, 129).

The presence of the suffix -ista is equally frequent in common names designating also a political tendency, or the membership of an organization. The specialized journals of political science offer many examples of them: agrarista, alternativista, brigadistas, foquista, sindicalista, and tercerista.

Another group of borrowings in which the Spanish suffix is well represented is the derivatives formed from acronyms, which are normally transferred. Apristas, Miristas, cenetistas, and forjistas are examples added to those examined in Rodríguez $(1980,155 ; 1988,73)$. I have only documented one containing the ending -ist, POUMist (a member of the POUM or Partido 
Obrero de Unificación Marxista), which is really a rather unusual occurrence in English (in contrast with German where, although the suffix is also disfavored, it occurs more frequently: Apoist [APO], Kapedisten [KPD], etc). The occurrence of such a peculiar form in one text, apart from the possible motivations based on its greater transparency-derived from the capitalization of the initials - seems to be prompted by the stylistic parallelism that has been formed with other derivatives which are close to one another: "This facilitated the incorporation of ex-anarcho-syndicalists, former POUMists, and even Trostkyists" (Benjamin Martin, "Spanish Socialists in Power," Dissent 31 [1984]: 117). ${ }^{2}$ In certain cases, however, the closeness of a derivative, especially if it has the same referential meaning, can be a source of variable usage: "It is a creation of the Unión Nacional Sinarquista (UNS), a 'synarchist' or quasi-fascist movement." (Ciarán Ó Maoláin, The Radical Right: A World Directory, Harlow: Longman 1987, 190).

Stylistic variability is also found in a variety of situations, sometimes involving derivatives with a high frequency of use. Thus, for example, in a single article the alternation Peronista/Peronist (< Perón) occurs in the following way: "Peronistas had promised ...," "Peronista demonstrations," "Peronista government," "Peronist movement," "Peronist politicos" ("A Dictator Returns to His Past," Time 27 Nov. 1972: 11).

Likewise, in another text one finds both Sandinista and Sandinist, which occur as follows: "the work of local CDS (Sandinist Defense Committees)," "Sandinista revolution," "Sandinista leaders," "Sandinistas," "Today, the insignia on army trucks and airplanes still do not read 'Nicaraguan' but 'Sandinist Popular Army' and 'Sandinist Air Force'" (Jean E. Corradi, "Nicaragua: Can It Find Its Own Way?" Dissent 31 [1984]: 277-84). In all the uses of -ist found in this text the derivative forms part of a denomination, which leads one to think of morphophonological and syntagmatic types of conditioning-by being shorter, the naturalized derivative favors a faster tempo which is more adequate to the greater extension of the syntagm of which it forms a part.

Another outstanding example of variation is contained in the following excerpt from the British journal The Guardian (8 Dec. 1983: 7): "US-backed anti-Sandinista guerrillas" and "Sandinistas are expecting" (Tony Jenkins, "Attack on Bus Signals Fresh Offensive against Sandinistas"); "The statement condemned Nicaragua's Sandinist government ... ." ("Mexico to Urge US to Cut Army Presence," Reuter wire service).

A close look into the context surrounding such forms soon leads us to notice a meaningful difference. Although in both cases the journalist is English-speaking, the first text (with -ista) is written by a news correspondent in Managua, who is therefore presumably accustomed to hearing this 
word, and possibly-given the leftist leanings of this liberal independent journal-sympathises with the prevailing local feelings associated with it. The latter, however, is signed by the British news agency Reuter, from which one could infer that the distance and a certain asepsis in dealing with the news would prompt the editor to make use of a more stylistically unmarked style, more Anglo-Saxon, as it were, which would appear as more neutral. There might be cases in which, given a different ideological stance of the speaker or journal, a negative attitude towards the term could be felt.

Ancther curious example of variation with derivatives is the pair franquista/ Francoist, as is found in one text of The Radical Right: A World Directory '(Ciarán Ó Maoláin, Harlow: Longman, 1987) in which the following fragments can be read:

At least three military coup plots have come to light. ... All three movements were apparently motivated by a desire to restore a FRANQUISTA dictatorship. Each of the plots, and in particular that of Tejero (who became an idol of the far right) was supported by some retired and serving military officers, fundamentalist Catholics opposed to the liberalization of social legislation, neo-nazi organizations and others of both conservative and fascist tendencies. [249]

This right-wing daily newspaper was founded in 1936, during the three-month siege of the FRANCOIST stronghold of the Alcázar, as the principal organ of the nationalist cause. Its circulation is mainly among Francorst veterans. . . Its editor and several of its senior staff are leading members of the FRANCOIST Juntas.... [250]

Closely examined, the alternation of both forms seems to be due not only to a wish to provide the text with a "variatio elegante" but also, and above all, with two different connotations: franquista, the Spanish variant, has in this case a clearly pejorative connotation and, as such, it proves more adequate when used, in collocation with dictatorship, to refer to the plotters of the failed coup d'état; the anglicized form, Francoist, used in describing the features of a newspaper, is more neutral and collocates with such words as stronghold, veterans, and Juntas.

Similar variations and semantic conditionings are often found with Spanish derivatives. In some cases, such as with somocista, fidelista, and franquista, the context reveals the pejorative character of the signifier, a quality which fits a descriptive rather than a referential or identifying usage, as noticed in the following sentences:

Further, the immediate expropriation in 1979 of 2.75 million acres formerly belonging to Somoza, his associates, or simply people whom the FSLN decided to call somocistas in order to take their land. .. . [Mark Falcoff, "Nicaraguan Harvest," Commentary 80.1 (1985): 25] 
The BOS claimed that its members had been discriminated against by US backers of the contra forces, presumably on the grounds that they were not keen to associate with somocista elements in the FDN and similar groups. [Ciarán Ó Maoláin, Latin American Political Movements, Harlow: Longman 1985, 182]

As it turned out the crop consisted mainly of North American left-wing academics, specialists in one or another of the social sciences or literature, who to this day have remained fidelistas (more or less) and who from their position in the universities contribute disproportionately to the formation of public opinion.... [Carlos Rangel, "Mexico \&c Other Dominoes," Commentary 71.6 (1981): 27]

In the following text, however, the unmarked spelling of Fidelista may be associated with the identifying function which characterizes the constituents of a denomination (cf. Conservatives in Conservative Party, or Repubiicans in Republican Party): "The leading 'old Communists' (former PSP members) were purged from the government in 1964-65 and replaced by Fidelistas from the July 26 Movement..." (Charles Hobday, Communist and Marxist Parties of the World, Harlow: Longman, 1986, 315).

\section{The Irradiation of The Suffix -ista}

The suffix -ista is so rooted in the derivational system of the language that it is sometimes affixed to native names (Evanista, Perotista, and evangelista). Since this is a novelty from recent years, it is worthwhile to analyze the instances in which the suffix occurs and to speculate as to its specific meaning.

As in the case of franquista, the negative tinge of the suffix becomes clear in evangelista, which denotes a 'politically active evangelist' (Algeo and Algeo 1993, 184). ${ }^{3}$ But it is also present in Evanistas and Perotistas, which are the appelatives given to the followers of the former governor of Arizona, Evan Mecham, and of the former presidential candidate, Ross Perot. Let us consider first Evanistas as found in this passage:

DeGraw says Mecham's loyal followers-called 'Evanistas' - back him more strongly now than ever. [Bill Nichols, "Arizona's Mecham May Pull off Rebound," USA Today 8 Mar. 1990: 6A]

Among the reasons that may have prompted the writer to use -ista with the English name Evan is the wish to provide the text with a Spanish context or atmosphere, for he is the governor of Arizona, a state with a large Spanish-speaking population which borders on Mexico. But the fact that this political figure did not have a good reputation among the general public-he was impeached and finally forced from office-may have also contributed to the selection of the suffix. 
Likewise, the popularity achieved by Ross Perot as a result of his candidacy, his involvement in fringe politics, and his outspoken manner have led him to be the subject of derision in many circles. This perhaps played a role in the use of Perotista in the following excerpts coliected by Algeo and Algeo (1993):

The media have tagged them Perobots, Perotians, Perotistas-names that give them a certain cachet, but also foster the image of a movement at the political fringe. [Debbie Howlett, "Not 'Perobot'-Just People: Supporters Resent Tag of 'Crazies.'" USA Today 28 Sept. 1992: 7A]

The Perotistas have been chastised by some critics for displaying an enthusiasm too close to blind faith. [Bill Hewitt, "Some Come Running," People 22 June 1992: 38]

Perotista, as well as other more humoristic variants such as Perobot, Perotian, Perotnik and Perotnista, is in marked contrast with Perotist, as used by a person who declared with pride:

"I am a Perotist," proclaimed Stanley Manin, a jeweler. "I'm tired of politics as usual." [Athens (GA) Banner-Herald 3 Nov. 1992: 14]

Perotistas seems to have taken deep root since the term is also found in fairly neutral contexts, within the "information" or "news" genre of American newsmagazines. Thus, in one issue of Newsweek, Perotistas appears within a diagram, aligned with other political labels (Liberal Democrats, New Dems, and Social Conservatives) as well as in the following text:

And Clinton's aids already are working feverishly to derail something Perotistas (and many others) love: a constitutional amendment requiring a balanced budget. [Howard Fineman, "The Four Faces of Bill Clinton," Newsweek 7 Feb. 1994: 17]

This connnotative ambivalence, together with the prevailing negative connotation and the Spanish heritage of the suffix to which I referred above, becomes explicit in the following comment from the New York Times, à propos of Clintonista:

Clintonista, though sometimes used neutrally, was the favorite of the Bush camp, implying as it does bomb-throwing Latin leftists. ["Eponymy," New York Times 8 Nov. 1992: sec. 4, 16]

\section{Conclusion}

The recent use of -ista with native terms, especially eponyms, in the political field is not accidental. Although many Hispanic terms ending in -ista have been used in English, none has been more frequently used in the media than Sandinista, as mentioned above. Certainly, the American obsession with Latin American politics, particularly in those countries with left- 
wing governments (Nicaragua and Cuba), and the singularity and popularity of the revolutionaries of these countries-a trend continuing today with the Mexican Zapatistas - are responsible for the popularity and diffusion of the suffix. In view of the high frequency of Sandinista, we may consider the role of this term similar in its effects to the analogical influence exerted by "leader words." ${ }^{4}$ However, the negative connotation has been more strongly and clearly felt in words with more personal associations such as peronista, somocista, franquista, and fidelista derived from names which stand for despotic political figures from the right and the left (Perón, Somoza, Franco, Fidel Castro) ${ }^{5}$

As to the "leading" role of Sandinista, in Peninsular Spanish, in the 1970s, there was a strikingly parallel case when the popular -ero suffix, which in itself had derogatory connotations, became fashionable with political derivatives (formed by acronyms) thanks to the popularity and news coverage received by a left-wing group, the Spanish Communist Party, or PCE. In the past, Spanish acronyms representing political parties had formed their derivatives with the aid of the suffix -ista, which had similar connotations (neutral or positive) to English-ist; however, after pecero was coined, the -ero suffix was extended with left-wing formations, such as psuquero (PSUC), petero (PTE), and psoero (PSOE). Later, the suffix was attached to all kinds of derivatives, regardless of the ideology and the parties involved, showing at times morphemic variation. Thus, with some derivatives, the suffix co-occurred with -ista, as well as some other variants (e.g., psoesista, psoero [PSOE], ucedista, ucedero [UCD], pedepista, pedepero [PDP]). In those cases the suffix -ero, like -ista in American English in the above-mentioned examples, was often used as a stylistic device to provide humorous or ironic connotations (cf. Rodríguez 1991, 177-82).

Furthermore, going back to hispanicisms, one should not forget that this varying connotative semanticism in the direction that I have pointed out is not an isolated fact but constitutes a very characteristic pattern of Spanish borrowings. There are examples in many walks of life, in fact, where the Spanish term has a pejorative connotation derived from its use to describe a degraded social reality, a fact which has passed unnoticed by many scholars. Thus, a hot tamale is a food term which is also taken to mean a sexually attractive woman, coyote is a depredatory animal which also designates someone who smuggles illegal migrants from Mexico to the United States, a tourista is a tourist travelling in Mexico but it also refers to dysentery (especially the kind often contracted by tourists in Mexico). ${ }^{6}$ The stigma and ill-repute of Mexicans and their reflection in the lexicon have a long history. Take for example the word hoosegow. Derived from juzgado, the past participle of Spanish juzgar 'to judge', in American slang it came to 
denote 'prison' (Webster), and this semantic shift allows us to imagine the extent and celerity with which Mexicans might have been convicted of crime in the past without being conceded the presumption of innocence. These hispanicisms, and many others that could be added, no doubt, are a sign of the stereotypic image Hispanics have in the eyes of Anglos. (For other examples, see Cotton and Sharp, forthcoming). Taken as a whole, they are in marked opposition to anglicisms in Spanish, which by way of cultural snobbery are often used to transmit more positive effects.

\section{Notes}

A preliminary version of this essay was presented at the XVIII Congreso de la Asociación Española de Estudios Anglo-Norteamericanos (AEDEAN), Aicalá de Henares (Madrid), 15-17 December 1994, bearing the title "Recent Spanish Contribution to English Word-Formation: The Suffix -ista." More supporting data on this subject can be found in "Hispanismos en la prensa angloamericana" (Rodríguez 1991, 249-73) and "Stylistic Aspects of Spanish Borrowings in the Political Press: Lexical and Morphological Variations," included in Rodríguez (ed., forthcoming), which provides a general, up-to-date study of Spanish borrowings in the English language. I am indebted to John Algeo for some recent data and to the anonymous reviewers of American Speech for critical comments and suggestions. Any shortcomings are, of course, my own responsibility.

1. The term comes from the imitation of a typical cigar name, of a cigar made with rope, and by extension it has come to denote the name of any inferior cigar, or any cigar that one does not like (cf. Murray, forthcoming).

2. Cf., however, the following text in which the acronym is not subject to derivation: "It was thus ranged against the left-wing Socialist, Anarchist and POUM (who called for a social revolution)..." (Charles Hobday, Communist and Marxist Parties of the World, Harlow: Longman, 1986, 126).

3. A similar pair to the semantic relation between E. evangelist and Sp. evangelista is found in E. church and Puerto Rican Sp. churcha 'a nonconfessional church'.

4. The powerful analogical pressure exerted by a particularly common noun in establishing a type was first suggested by German philologists (Gamillscheg, Meyer-Lübke), but it was further developed and popularized by Malkiel (1950-51) in an article in which he gave the concept special attention. The examples analyzed were Spanish derivatives from names of animals that ended in -uno, for which he regarded cabruno as the "leader word" (cf. also Pattison 1975, 161).

5. Sandinistas has a personal reference of a rather different kind. In the common use of the term, it referred to the members or sympathisers of the Nicaraguan Frente Sandinista de Liberación Nacional Sandinista (FSLN) whose ideals were inspired by Augusto César Sandino, an historical figure who is considered a national hero.

6 . It could be argued that tourista, attested in American English since the early 1960s (cf. Murray, forthcoming) is an -ista (nonpolitical) term derived from tour, which also presents the above-mentioned negative associations, of a both connotative and denotative kind. But the term is a morphological variant of turista which was borrowed directly from Spanish (cf. Cannon, forthcoming). 


\section{REFERENCES}

Algeo, John, and Adele Algeo. 1993. "Among the New Words." American Speech 68: 178-204.

Bolinger, Dwight. 1941. "Among the New Words." American Speech 16: 306-07.

Cannon, Garland. 1981. "Japanese Borrowings in English." American Speech 56: $190-206$.

- 1994. "Modern Spanish-Based Lexica! Items in English." Dictionaries 15: $117-31$

- Forthcoming. "Recent Borrowings from Spanish." Rodríguez (forthcoming).

Cotton, Eleanor, and John Sharp. Forthcoming. "The Anglo-American Stereotype of the Hispanic as Reflected in Loanwords." Rodríguez (forthcoming).

Dressman, Michael R. 1985. "The Suffix -isi." American Speech 60: 238-43.

Malkiel, Yakov. 1950-51. "The Latin Background of the Spanish Suffix -uno." Romance Philology 4: 17-45.

Murray, Thomas. Forthcoming. "Spanish Borrowings in Contemporary American Slang." Rodriguez (forthcoming).

Pattison, D. G. 1975. Early Spanish Suffixes. Oxford: Blackwell.

Rodríguez, Félix. 1980. "Estudio lingüístico de las siglas en español actual." Diss. U of Alberta.

- 1988. "The Proliferation and Use of Acronym Derivatives: Conditioning Factors." Cahiers de lexicologie 52: 111-26.

-1991. Prensa y lenguaje politico. Madrid: Fundamentos.

- ed. Forthcoming. Spanish Loanwords in the English Language. Berlin: Mouton de Gruyter.

Wentworth, Harold. 1942. "The Neo-Pseudo-Suffix -eroo." American Speech 17.1: 1015.

Félix Rodríguez González

University of Alicante, Spain

\section{WOMYN: THE EVIDENCE}

Contrary to the conventional wisdom, many people regard lexicographers as HARMFul drudges. Charges running the gamut from bias and permissiveness to political correctness and prescriptivism are often leveled at dictionary editors both by users and media commentators. A specific target of criticism is usually an entry whose inclusion or definition supposedly reflects editorial tendentiousness or an undisclosed agenda. The most popular target in recent years has been the entry nigger; formerly the verb jew down came under heavy attack. It seems insufficient to the critics that these entries, as indeed all ethnic and other types of slurs, are labeled in the dictionary as disparaging, derogatory, offensive, and the like. Implicit in 